\title{
Late Pleistocene insects from the Dubrovino site at Ob River (West Siberia, Russia) and their paleoenvironmental significance
}

\author{
Anna A. Gurina, Roman Yu. Dudko, Sergey E. Tshernyshev, \\ Eugeny V. Zinovyev, and Andrei A. Legalov
}

\begin{abstract}
A blue-grey clay loam lens with plant and insect remains was found in an exposure of the Ob River, $2 \mathrm{~km}$ upper Dubrovino village in Novosibirskaya Oblast of Russia. Conventional radiocarbon dating of the Dubrovino deposit is ca $19,444 \pm 159{ }^{14} \mathrm{C}$ BP $(23,234 \pm 338 \mathrm{cal}$ yr BP) and coincides with Sartan glaciation period (MIS 2). Ninety-two Coleoptera species, dominated by fragments of Curculionidae and Carabidae are represented in the Dubrovino deposit. Species of the tundra-steppe fauna are dominant, followed by meadow-dwelling taxa and coniferous forest taxa. A comparison of the Dubrovino assemblage with the previously studied late Pleistocene Kalistratikha and Bunkovo fossil assemblages showed that tundra-steppe landscapes with coniferous groves and sparse meadow vegetation were typical for this area from the end of Kargin interglacial (MIS 3) through the end of the Sartan glaciation (MIS 2).
\end{abstract}

Anna A. Gurina. Institute of Systematics and Ecology of Animals, Siberian Branch of Russian Academy of Sciences, Frunze Street 11, Novosibirsk 630091, Russia. auri.na@mail.ru

Roman Yu. Dudko. Institute of Systematics and Ecology of Animals, Siberian Branch of Russian Academy of Sciences, Frunze Street 11, Novosibirsk 630091, Russia. rdudko@mail.ru

Sergey E. Tshernyshev. Institute of Systematics and Ecology of Animals, Siberian Branch of Russian

Academy of Sciences, Frunze Street 11, Novosibirsk 630091, Russia and Tomsk State University, Lenina Prospekt 36, Tomsk 634050, Russia.sch-sch@mail.ru

Eugeny V. Zinovyev. Institute of Plant and Animal Ecology, Ural Branch of Russian Academy of Sciences, Vos'mogo Marta Street 202, Yekaterinburg 620144, Russia. zin62@mail.ru

Andrei A. Legalov*. Institute of Systematics and Ecology of Animals, Siberian Branch of Russian Academy of Sciences, Frunze Street 11, Novosibirsk 630091, Russia and Tomsk State University, Lenina Prospekt 36, Tomsk 634050, Russia. fossilweevils@gmail.com

Keywords: paleoecology; sub-fossil insects; late Pleistocene; paleoenvironment; Siberia

Submission: 11 August 2018 Acceptance: 10 December 2018

Gurina, Anna A., Dudko, Roman Yu., Tshernyshev, Sergey E., Zinovyev, Eugeny V., and Legalov, Andrei A. 2019. Late Pleistocene insects from the Dubrovino site at Ob River (West Siberia, Russia) and their paleoenvironmental significance. Palaeontologia Electronica 22.1.3A 1-18. https://doi.org/10.26879/914

palaeo-electronica.org/content/2019/2377-pleistocene-insects-ob-river

Copyright: January 2019 Paleontological Society.

This is an open access article distributed under the terms of the Creative Commons Attribution License, which permits unrestricted use, distribution, and reproduction in any medium, provided the original author and source are credited.

creativecommons.org/licenses/by/4.0/ 


\section{INTRODUCTION}

Insect remains in Quaternary deposits have typically been found in the temperate and high latitudes, and are especially well-preserved in permafrost regions. These fossils are widely used for the reconstruction of past environments (Nazarov, 1984; Elias, 1994; Coope and Lemdahl, 1995; Sher et al., 2005). Chitin is poorly preserved in tropical and subtropical regions, although insect diversity and abundance is much greater there (Buckland and Coope, 1991).

Late Pleistocene insects are known from deposits on the southern part of the West Siberian Plain and have recently been described from sites in the territory of Novosibirskaya Oblast and Altaiskii Krai (Tsepelev et al., 2013; Tshernyshev et al., 2013; Zinovyev et al., 2016; Kuzmina, 2017; Gurina et al., 2018). One of the fossil deposits was discovered in the bank of Ob River near Dubrovino Village (ca $55^{\circ} 27^{\prime} \mathrm{N}$ ), with calibrated radiocarbon age of $23,234 \pm 338$ cal BP (SPb-1417), that coincides with Marine isotope stage 2 (MIS 2) and the Sartan glaciation period according to Siberian regional scale. Similar age Quaternary insect deposits have not previously been described from the southern and central parts of the West Siberian Plain. This paper presents data on the fossil Coleoptera from this deposit as well as a paleoenvironmental reconstruction based on the insect faunal assemblage.

\section{STUDY AREA}

The Dubrovino deposit is located in the southern part of forest zone of West Siberian Plain (Figure 1). Pine forests including Pinus sibirica Du Tour, Betula pendula Roth., B. alba L., Sorbus sibirica Hedl. and rarely with Larix sibirica Ledeb. are represented in the studied area. The regional climate is continental with great changes in air temperature on a daily, seasonal and annual basis; the annual precipitation ranges from $380-430 \mathrm{~mm}$. The average temperature of the warmest month, July, is $+19.3{ }^{\circ} \mathrm{C}$, and the coldest, January, is $-17.7^{\circ} \mathrm{C}$ (Luchitskaia et al., 2014).

\section{GEOLOGICAL SETTINGS}

The deposit is located on the right bank of the Ob River, $2 \mathrm{~km}$ above Dubrovino village in Moshkovskii District of the Novosibirkaya Oblast of Russia, $40 \mathrm{~km}$ north of Novosibirk city. The site coordinates are: $55^{\circ} 27^{\prime} 07.0^{\prime \prime} \mathrm{N}, 83^{\circ} 15^{\prime} 17.7^{\prime \prime} \mathrm{E}$. The deposit is in a $13 \mathrm{~m}$ cliff. The lower part of the sequence, at 12.6-12.9 m depth, contains alluvial detritus with insect remains. Samples for entomological and radiocarbon analysis were taken from this organic-rich deposit in August 2014. A sedimentary description of the Dubrovino deposit profile is presented in Table 1 and Figure 2.

\section{MATERIAL AND METHODS}

Sampling methods follow those of Coope (1959) with later updates (Medvedev, 1968; Morgan, 1969, 1988; Nazarov, 1984; Kiselev et al., 1987). For geological description of the profile and to prevent contamination by modern insect fragments, the upper layer in the cliff was cleaned to produce a fresh exposure. The layer of sediments containing detritus and insect remains was placed in a large volume of filtered river water. The suspension was then washed through the sieve with cell diameter $0.3 \mathrm{~mm}$. The sediment, containing a mixture of plant detritus and insect fragments, was

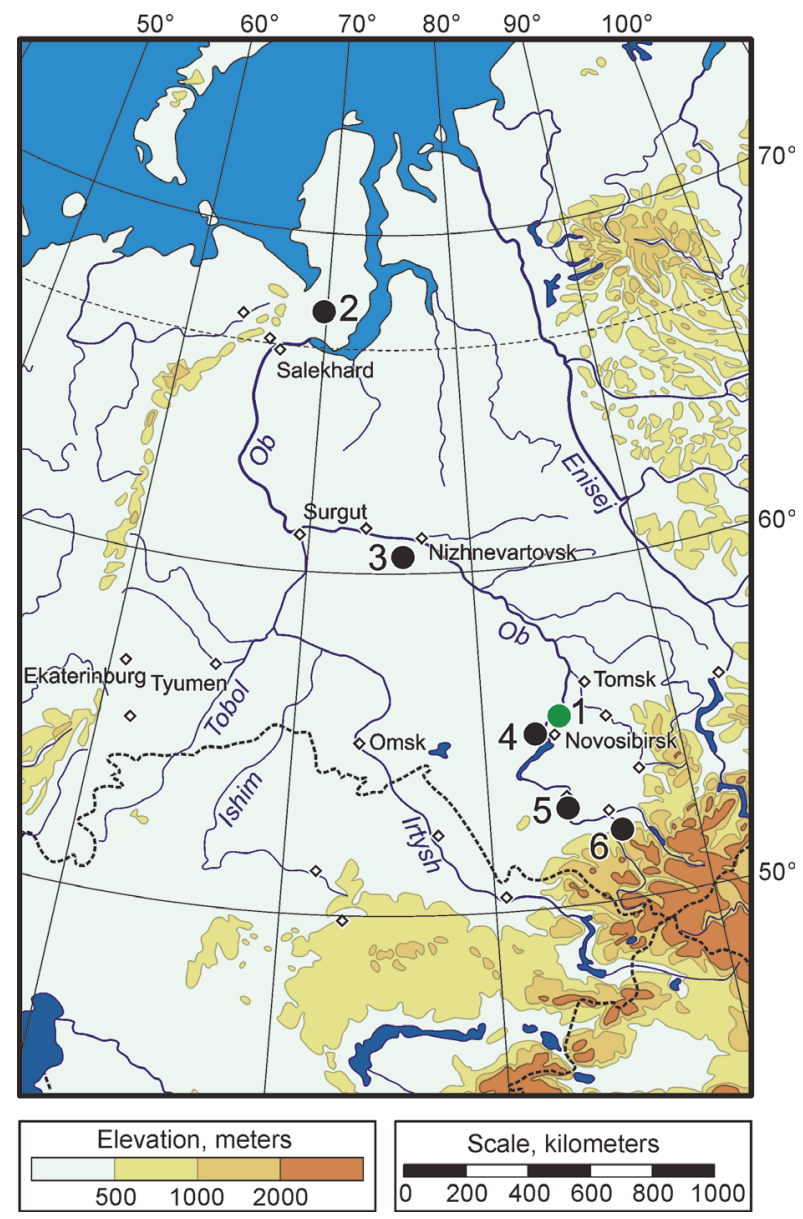

FIGURE 1. Locality map of Dubrovino site and similarage late Pleistocene deposits from the West Siberian Plain. 1, Dubrovino; 2, Tyurseda-Khadyta; 3, Kul'egan2247; 4, Bun'kovo; 5, Kalistratikha; 6, Novaya Surtaika. 
TABLE 1. Description of the Dubrovino section.

\begin{tabular}{cccl}
\hline Layer No. & $\begin{array}{c}\text { Elevation } \\
(\mathbf{m})\end{array}$ & $\begin{array}{c}\text { Thickness } \\
(\mathbf{m})\end{array}$ & \multicolumn{1}{c}{ Description } \\
\hline 8 & $12.7-13.0$ & 0.3 & Modern soil \\
7 & $12.0-12.7$ & 0.7 & Sandy loam consistent, dry, whitish, with ferruginous interlayer in lower part \\
6 & $7.1-12.0$ & 4.9 & Horizontal alternation of medium and coarse-grained sands \\
5 & $6.9-7.1$ & 0.2 & Interlayer with fine and compact light-grey sand \\
4 & $4.4-6.9$ & 2.5 & Alternation of medium sands and coarse-grained sands; in right side coarse-grained \\
& & & sands are turning into sandy gravel with fragments fragment of cbivalve shells \\
3 & $0.4-4.4$ & 4.0 & Alternation of fine-grained sands, loamy sands and grey-brown loams \\
$2^{*}$ & $0.1-0.4$ & 0.3 & Grey loam with a streak of alluvial detritus \\
1 & $0-0.1$ & $>0.1$ & Rufous clay extending under water surface \\
\hline
\end{tabular}

*Sample upper $0.2 \mathrm{~m}$ (12.6-12.8 m from the surface) with insect remains and phytodetritus for dating.

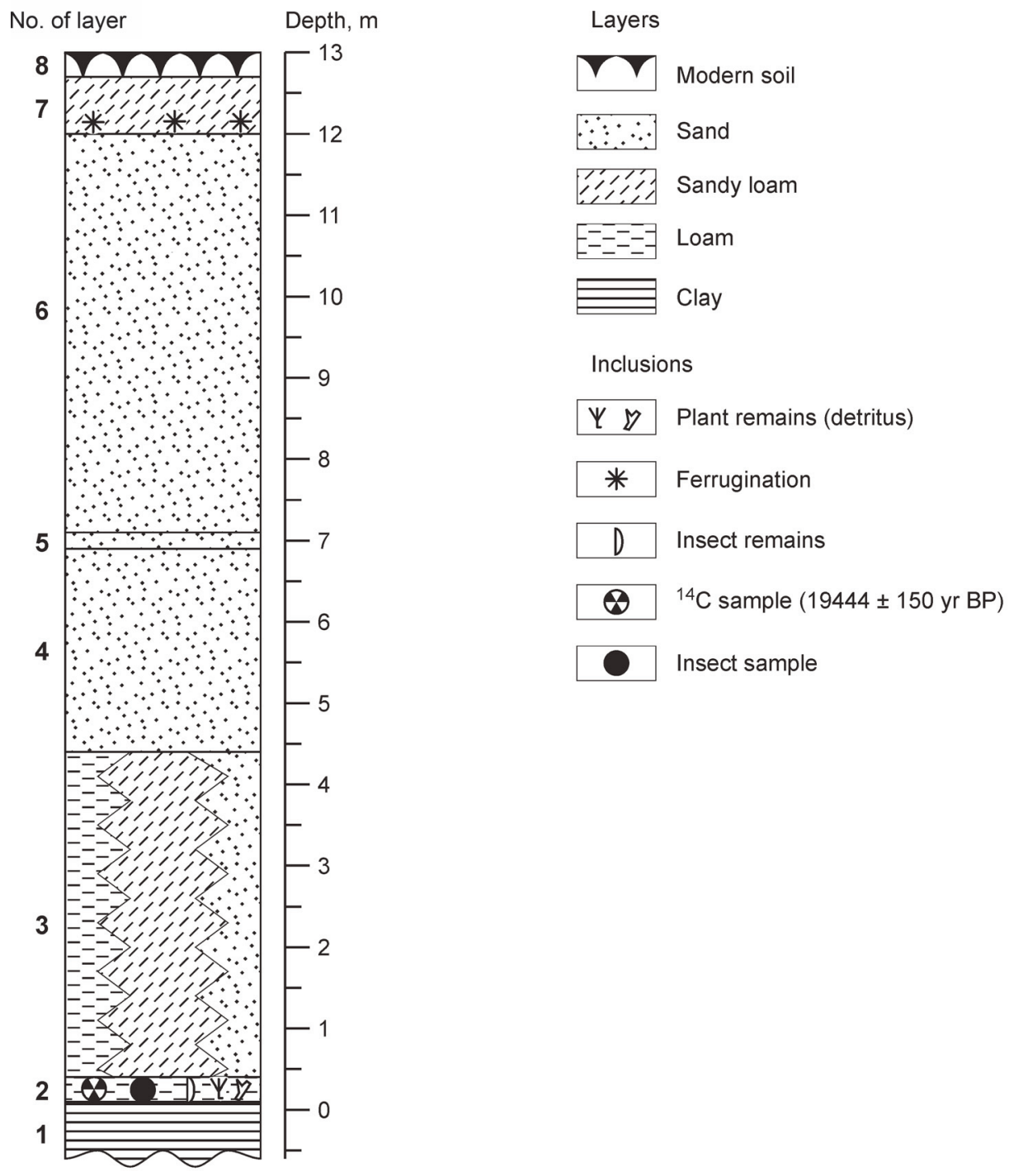

FIGURE 2. Stratigraphic diagram of the Dubrovino section on the Ob River. 
examined, and the insect remains were placed in a vial with $30 \%$ alcohol. Other detritus containing chitin was collected in a plastic bag. Further study of these samples took place in the laboratory. The sample was sieved meshes of $3 \mathrm{~mm}, 1 \mathrm{~mm}$ and 0.3 $\mathrm{mm}$, respectively. The sieved fractions were airdried, and the remaining insect fragments were picked under a binocular microscope.

The fragments were mounted with water-soluble glue onto entomological cards or placed in general plate, as each fragment was given a number entered into a digital database. Each fragment was then studied and identified by taxonomic specialists of the different beetle groups.

The sample was dated by radiocarbon analysis, yielding an age of $19,444 \pm 159{ }^{14} \mathrm{C} \mathrm{BP}$ (SPb1417). The calibrated age using the Calpal Online (http://www.calpal-online.de) is $23,234 \pm 338 \mathrm{cal} \mathrm{yr}$ BP. This age coincides with the beginning of MIS 2 or Sartan glaciation of the late Pleistocene.

\section{RESULTS}

\section{Taxonomic Composition of Beetles in the Dubrovino Assemblage}

Fossil beetle results are presented in Table 2 . Photos of fossil insects are presented in Figures 34. A total of 92 beetle species from 15 families were identified from the Dubrovino deposit. The faunal composition was as follows: $74 \%$ of the fauna were weevils and carabids (33 and 34 species, respectively), $6 \%$ were pill beetles (Byrrhidae, 5 species), and each of the remaining 12 families were represented by just $1-3$ species. The majority of species in the assemblage are typical of late Pleistocene deposits from the southern and central parts of West Siberia (Zinovyev, 2011, Legalov et al., 2016; Zynovyev et al., 2016), but a number of species are recorded here for the first time, namely: Nebria cf. rubrofemorata Shilenkov, 1975; Trechus cf. compactulus Belousov and Kabak, 1996; Pterostichus cf. tomensis (Gebler, 1847); Aphodius multiplex Reitter, 1867; Stephanocleonus favens Faust, 1884; S. isochromus Suvorov, 1912; Lixus paraplecticus (Linnaeus, 1758); Ceutorhynchus ignitus Germar, 1823; Otiorhynchus beatus Faust, 1890; and O. janovskii Korotyaev, 1990.

The majority of fragments ( $N=1050,72 \%)$ from the deposit belong to Curculionidae, next numerous (201 fragments, 14\%) are Carabidae, and fragments of remaining species share $13 \%$. Otiorhynchus Germar, 1822 specimens are the most numerous (897 fragments, $55 \%$ ), dominated by two closely related species $O$. altaicus Stierlin,
1861; and O. ursus Gebler, 1844 (550 fragments, $39 \%$ ), and also O. obscurus Gyllenhal in Schoenherr, 1834 (84 fragments); and O. politus Gyllenhal in Schoenherr, 1834 (51 fragments). Also abundant are Tournotaris bimaculata (Fabricius, 1787) (Curculionidae) (65 fragments, 5\%); and Poecilus (Derus) spp. (Carabidae) (31 fragments, 2\%).

\section{Ecological Groups}

The ecological preferences of the insects found in the Dubrovino deposit are diverse and represent members of steppe, forest, tundra, meadow, water and saline species-complexes.

The steppe complex is the best-represented, based on the number of species and specimens. Xerophilous and meso-xerophilous beetles typical of steppe habitats, including Poecilus ravus (Lutshnik, 1922); Poecilus fortipes (Chaudoir, 1850); Pterostichus macer (Marsham, 1802); Cymindis arctica Kryzhanovskij and Emetz, 1979; Metadonus distinguendus (Boheman in Schoenherr, 1842); Tychius albolineatus Motschulsky, 1860; Stephanocleonus eruditus Faust, 1890; S. favens; S. fossulatus (Fischer von Waldheim, 1823); S. isochromus; S. leucopterus (Fischer von Waldheim, 1823); Phyllobius femoralis Boheman in Schoenherr, 1842; Otiorhynchus beatus; O. altaicus; O. ursus; O. obscurus; O. unctuosus Germar, 1823. Most of these are known from other late Pleistocene assemblages in the south and central part of the West Siberian Plain that have also yielded cold-dry environmental reconstructions (Zinovyev, 2011; Tshernyshev et al., 2013; Zinovyev et al., 2016; Legalov et al., 2016).

Forest species are represented in the fossil assemblage by only four species, i.e., Notiophilus fasciatus Mäklin, 1855; Pterostichus tomensis; Hylobius excavatus (Laicharting, 1781); and Pissodes insignatus Boheman in Schoenherr, 1843. These are typical of coniferous (taiga) forests and indicate the presence of conifers in the study region at the beginning of MIS 2 .

Cold-adapted boreo-arctic species that inhabit tundra and forest-tundra ecotone regions include Diacheila polita (Faldermann, 1835); P. (Cryobius) spp.; Notaris aethiops (Paykull, 1792); Lepyrus nordenskioldi Faust in Sahlberg, 1887; and Hypera ornata (Capiomont, 1868).

Species typical of various meadow habitats are as follows: Trechus compactulus; Olisthopus sturmii (Duftschmid, 1812); Phyllobius virideaeris (Laicharting, 1781); Polydrusus amoenus (Germar, 1823); Otiorhynchus grandineus Germar, 1823; and O. politus. 
TABLE 2. Species composition and number of insect fragments in Dubrovino taphocoenosis. HD = head, $P R=$ pronotum, $\mathrm{EL}=$ elytra, $\mathrm{OT}=$ other fragments, $\mathrm{N}_{\min }=$ minimum number of specimens.

\begin{tabular}{|c|c|c|c|c|c|c|c|}
\hline \multirow[b]{2}{*}{ No. } & \multirow[b]{2}{*}{ Species } & \multirow[b]{2}{*}{ Distribution* $^{*}$} & \multicolumn{4}{|c|}{ Type of fragment } & \multirow[b]{2}{*}{$\mathbf{N}_{\min }$} \\
\hline & & & HD & PR & EL & OT & \\
\hline \multicolumn{8}{|c|}{ Carabidae } \\
\hline 1 & Notiophilus cf. aquaticus (Linnaeus, 1758) & + & - & - & 2 & - & 2 \\
\hline 2 & Notiophilus fasciatus Mäklin, 1855 & North & - & - & 1 & - & 1 \\
\hline- & Notiophilus sp. & & - & - & 1 & - & 1 \\
\hline 3 & Nebria cf. rubrofemorata Shilenkov, 1975 & East & - & - & 1 & - & 1 \\
\hline 4 & Nebria subdilatata Motschulsky, 1844 & East & - & - & 1 & - & 1 \\
\hline 5 & Diacheila polita (Faldermann, 1835) & North & - & - & 1 & - & 1 \\
\hline 6 & Elaphrus cf. riparius (Linnaeus, 1758) & + & 1 & 2 & - & - & 2 \\
\hline- & Elaphrus sp. & - & - & - & 2 & 1 & 1 \\
\hline 7 & Clivina fossor (Linnaeus, 1758) & + & - & 2 & 2 & - & 2 \\
\hline 8 & Trechus cf. compactulus Belousov and Kabak, 1996 & East & - & - & 2 & - & 2 \\
\hline 9 & Trechus sp. 1 & - & - & - & 3 & - & 2 \\
\hline 10 & Bembidion (Plataphodes) cf. fellmanni (Mannerheim, 1823) & North & - & - & 1 & - & 1 \\
\hline- & Bembidion (Plataphodes) sp. & - & - & - & 1 & - & 1 \\
\hline 11 & Bembidion (Plataphus) sp. & - & - & - & 2 & - & 2 \\
\hline 12 & Bembidion (Peryphus) dauricum (Motschulsky, 1844) & East & - & - & 4 & - & 3 \\
\hline 13 & Bembidion (Asioperyphus) spp. & - & 4 & - & - & - & 4 \\
\hline 14 & Bembidion (Pamirium) sp. & South & - & - & 1 & - & 1 \\
\hline- & Bembidion sp. & - & - & - & 1 & 4 & 1 \\
\hline 15 & Pogonus iridipennis Nicolai, 1822 & South & - & 1 & - & - & 1 \\
\hline 16 & Pogonus punctulatus Dejean, 1828 & South & - & 3 & 3 & - & 3 \\
\hline 17 & Patrobus cf. septentrionis Dejean, 1828 & + & - & - & 1 & - & 1 \\
\hline 18 & Poecilus (Derus) cf. ravus (Lutshnik, 1922) & East & - & 6 & 9 & - & 5 \\
\hline 19 & Poecilus (Derus) sp. 1 & - & - & 12 & 6 & - & 11 \\
\hline 20 & Poecilus (Poecilus) fortipes (Chaudoir, 1850) & + & - & 1 & - & - & 1 \\
\hline 21 & Pterostichus (Lyperopherus) mirus (Tschitschérine, 1894) & East & - & 1 & - & - & 1 \\
\hline 30 & Pterostichus (Adelosia) macer (Marsham, 1802) & South & - & 1 & - & - & 1 \\
\hline 22 & Pterostichus (Cryobius) cf. brevicornis (Kirby, 1837) & North & - & 2 & 1 & - & 2 \\
\hline 23 & Pterostichus (Cryobius) spp. & North? & - & 3 & 6 & - & 4 \\
\hline 24 & Pterostichus (Petrophilus) cf. tomensis (Gebler, 1847) & East & - & 2 & - & - & 2 \\
\hline 25 & Pterostichus (Petrophilus) sp. 1 & - & - & 2 & - & - & 2 \\
\hline- & Pterostichus spp. & - & - & 2 & 3 & - & 4 \\
\hline 26 & Amara (Amara) sp. & - & - & - & 1 & - & 1 \\
\hline 27 & Amara (Bradytus) aurichalcea Germar, 1823 & North & - & 1 & - & - & 1 \\
\hline 28 & Curtonotus sp. & - & - & 4 & 3 & - & 4 \\
\hline 29 & Agonum sp. & - & - & - & 1 & - & 1 \\
\hline 30 & Olisthopus sturmii (Duftschmid, 1812) & + & - & - & 1 & - & 1 \\
\hline 31 & Harpalus spp. & - & 2 & 3 & - & - & 3 \\
\hline 32 & Cymindis cf. arctica Kryzhanovskij and Emetz, 1979 & East & 1 & 5 & - & - & 5 \\
\hline- & Cymindis spp. & - & 1 & - & 1 & - & 1 \\
\hline- & Carabidae indet. & - & 25 & - & 7 & 55 & - \\
\hline
\end{tabular}


TABLE 2 (continued).

\begin{tabular}{|c|c|c|c|c|c|c|c|}
\hline \multirow[b]{2}{*}{ No. } & \multirow[b]{2}{*}{ Species } & \multirow[b]{2}{*}{ Distribution* } & \multicolumn{4}{|c|}{ Type of fragment } & \multirow[b]{2}{*}{$\mathrm{N}_{\min }$} \\
\hline & & & HD & PR & EL & От & \\
\hline \multicolumn{8}{|c|}{ Hydrophilidae } \\
\hline 33 & Cymbiodyta marginella (Fabricius, 1792) & + & - & - & - & 1 & 1 \\
\hline 34 & Cercyon sp. & - & - & - & 1 & - & 1 \\
\hline \multicolumn{8}{|c|}{ Helophoridae } \\
\hline 35 & Helophorus spp. & - & - & - & 6 & - & 3 \\
\hline \multicolumn{8}{|c|}{ Leiodidae } \\
\hline 36 & Leiodidae indet. & - & - & - & 1 & - & 1 \\
\hline \multicolumn{8}{|c|}{ Silphidae } \\
\hline 37 & Thanatophilus spp. & - & - & 1 & 4 & - & 2 \\
\hline- & Silphidae indet. & - & 1 & 5 & 1 & - & 5 \\
\hline \multicolumn{8}{|c|}{ Staphylinidae } \\
\hline 38 & Tachinus sp. & - & - & - & - & 1 & 1 \\
\hline 39 & Omaliinae indet. & - & - & 1 & - & - & 1 \\
\hline- & Staphylinidae indet. & - & - & 3 & 1 & - & 3 \\
\hline \multicolumn{8}{|c|}{ Scarabaeidae } \\
\hline 40 & Aegialia cf. abdita Nikritin, 1975 & North & - & - & 1 & - & 1 \\
\hline 41 & Aphodius multiplex Reitter, 1867 & South & 1 & - & - & - & 1 \\
\hline 42 & Aphodius dictinctus (O.F. Müller, 1776) & + & - & - & 1 & - & 1 \\
\hline 43 & Aphodius sp. & - & 4 & 7 & 15 & 2 & 8 \\
\hline \multicolumn{8}{|c|}{ Byrrhidae } \\
\hline 44 & Lamprobyrrhulus nitidus (Schaller, 1783) & + & 1 & 3 & 5 & & 3 \\
\hline 45 & Morychus ostasiaticus Tshernyshev, 1997 & East & - & - & 4 & 2 & 2 \\
\hline 46 & Porcinolus murinus (Fabricius, 1794) & South & - & - & 1 & - & 1 \\
\hline 47 & Simplocaria elongata J. Sahlberg, 1903 & North & - & - & 1 & - & 1 \\
\hline 48 & Cytilus sericeus (Foerster, 1771) & + & - & - & 1 & 1 & 1 \\
\hline \multicolumn{8}{|c|}{ Elateridae } \\
\hline 49 & Hypnoidus sp. & - & - & 1 & 3 & - & 2 \\
\hline 50 & Elateridae indet. & - & - & - & 4 & 4 & 2 \\
\hline \multicolumn{8}{|c|}{ Coccinellidae } \\
\hline 51 & Coccinella sp. & - & - & 1 & - & 1 & 1 \\
\hline 52 & Scymnus sp. & - & - & - & 1 & - & 1 \\
\hline \multicolumn{8}{|c|}{ Tenebrionidae } \\
\hline 53 & Centorus rufipes (Gebler, 1833) & South & - & 7 & - & - & 7 \\
\hline \multicolumn{8}{|c|}{ Anobiidae } \\
\hline 54 & Xyletinus sp. & - & - & - & 1 & - & 1 \\
\hline \multicolumn{8}{|c|}{ Chrysomelidae } \\
\hline 55 & Hydrothassa hannoveriana (Fabricius, 1775) & North & - & - & 1 & - & 1 \\
\hline 56 & Chrysomelidae indet. & - & - & 3 & 2 & 1 & 3 \\
\hline \multicolumn{8}{|c|}{ Brentidae } \\
\hline 57 & Mesotrichapion punctirostre (Gyllenhal in Sch & South & - & - & 3 & - & 2 \\
\hline 58 & Apioninae indet. & - & - & - & 19 & 6 & 10 \\
\hline
\end{tabular}


TABLE 2 (continued).

\begin{tabular}{|c|c|c|c|c|c|c|c|}
\hline \multirow[b]{2}{*}{ No. } & \multirow[b]{2}{*}{ Species } & \multirow[b]{2}{*}{ Distribution* } & \multicolumn{4}{|c|}{ Type of fragment } & \multirow[b]{2}{*}{$\mathbf{N}_{\min }$} \\
\hline & & & HD & PR & EL & От & \\
\hline \multicolumn{8}{|c|}{ Curculionidae } \\
\hline 59 & Tournotaris bimaculata (Fabricius, 1787) & + & 13 & 19 & 12 & 23 & 19 \\
\hline 60 & Notaris aethiops (Paykull, 1792) & North & 18 & 1 & - & 1 & 18 \\
\hline 61 & Thryogenes nereis (Paykull, 1800) & + & 1 & 1 & 1 & - & 1 \\
\hline 62 & Hylobius excavatus (Laicharting, 1781) & North & - & - & 1 & - & 1 \\
\hline 63 & Pissodes insignatus Boheman in Schoenherr, 1843 & East & - & - & 1 & - & 1 \\
\hline 64 & Lepyrus nordenskioldi Faust in Sahlberg, 1887 & North & 1 & - & - & - & 1 \\
\hline 65 & Lepyrus sp. & - & - & - & - & 1 & 1 \\
\hline 66 & Lixus paraplecticus (Linnaeus, 1758) & + & - & - & 2 & - & 1 \\
\hline 67 & Stephanocleonus eruditus Faust, 1890 & East & 4 & - & 2 & - & 4 \\
\hline 68 & Stephanocleonus favens Faust, 1884 & East & 1 & - & - & - & 1 \\
\hline 69 & Stephanocleonus fossulatus (Fischer von Waldheim, 1823) & East & 1 & - & - & - & 1 \\
\hline 70 & Stephanocleonus isochromus Suvorov, 1912 & East & 2 & - & - & - & 2 \\
\hline 71 & Stephanocleonus leucopterus (Fischer von Waldheim, 1823) & South & 1 & - & - & - & 1 \\
\hline 72 & Coniocleonus sp. & - & - & - & - & 1 & 1 \\
\hline- & Cleonini gen. sp. & - & - & - & 2 & - & - \\
\hline 73 & Ceutorhynchus ignitus Germar, 1823 & + & - & - & 1 & - & 1 \\
\hline 74 & Tychius albolineatus Motschulsky, 1860 & South & - & - & 1 & - & 1 \\
\hline \multirow[t]{2}{*}{75} & Hypera ornata (Capiomont, 1868) & North & - & 1 & - & - & 1 \\
\hline & Hypera sp. & - & - & - & - & 1 & 1 \\
\hline 76 & Metadonus distinguendus (Boheman in Schoenherr, 1842) & + & 1 & 1 & - & - & 1 \\
\hline 77 & Trichalophus biguttatus (Gebler, 1832) & East & 1 & - & - & - & 1 \\
\hline 78 & Sitona sp. & - & 2 & 14 & - & - & 14 \\
\hline 79 & Chlorophanus sibiricus Gyllenhal in Schoenherr, 1834 & + & - & - & - & 1 & 1 \\
\hline 80 & Phyllobius femoralis Boheman in Schoenherr, 1842 & East & 1 & - & - & - & 1 \\
\hline \multirow[t]{2}{*}{81} & Phyllobius virideaeris (Laicharting, 1781) & + & 3 & 1 & 2 & - & 3 \\
\hline & Phyllobius spp. & - & - & 4 & 14 & 6 & 7 \\
\hline 82 & Polydrusus amoenus (Germar, 1823) & North & 7 & - & - & - & 7 \\
\hline 83 & Otiorhynchus arcticus (O. Fabricius, 1780) & North & - & 1 & - & - & 1 \\
\hline 84 & Otiorhynchus beatus Faust, 1890 & East & - & - & 2 & - & 1 \\
\hline 85 & Otiorhynchus grandineus Germar, 1823 & East & - & - & 2 & - & 1 \\
\hline 86 & Otiorhynchus janovskii Korotyaev, 1990 & East & - & 2 & 13 & - & 7 \\
\hline 87 & Otiorhynchus altaicus Stierlin, 1861 & South & 220 & 165 & 103 & 82 & 220 \\
\hline 88 & Otiorhynchus ursus Gebler, 1844 & South & & & 13 & & \\
\hline 89 & Otiorhynchus obscurus Gyllenhal in Schoenherr, 1834 & South & 19 & 41 & 13 & 11 & 41 \\
\hline 90 & Otiorhynchus politus Gyllenhal in Schoenherr, 1834 & North & 4 & 11 & 6 & 18 & 11 \\
\hline 91 & Otiorhynchus pullus Gyllenhal in Schoenherr, 1834 & South & 1 & 6 & 2 & - & 6 \\
\hline 92 & Otiorhynchus unctuosus Germar, 1823 & South & - & 1 & 11 & - & 6 \\
\hline- & Otiorhynchus sp. & - & - & - & - & 19 & - \\
\hline- & Coleoptera indet. & - & 17 & 3 & - & 5 & - \\
\hline- & Hymenoptera indet. & - & 5 & - & - & 7 & 5 \\
\hline
\end{tabular}

* Modern distribution in comparison with the Dubrovino site. 

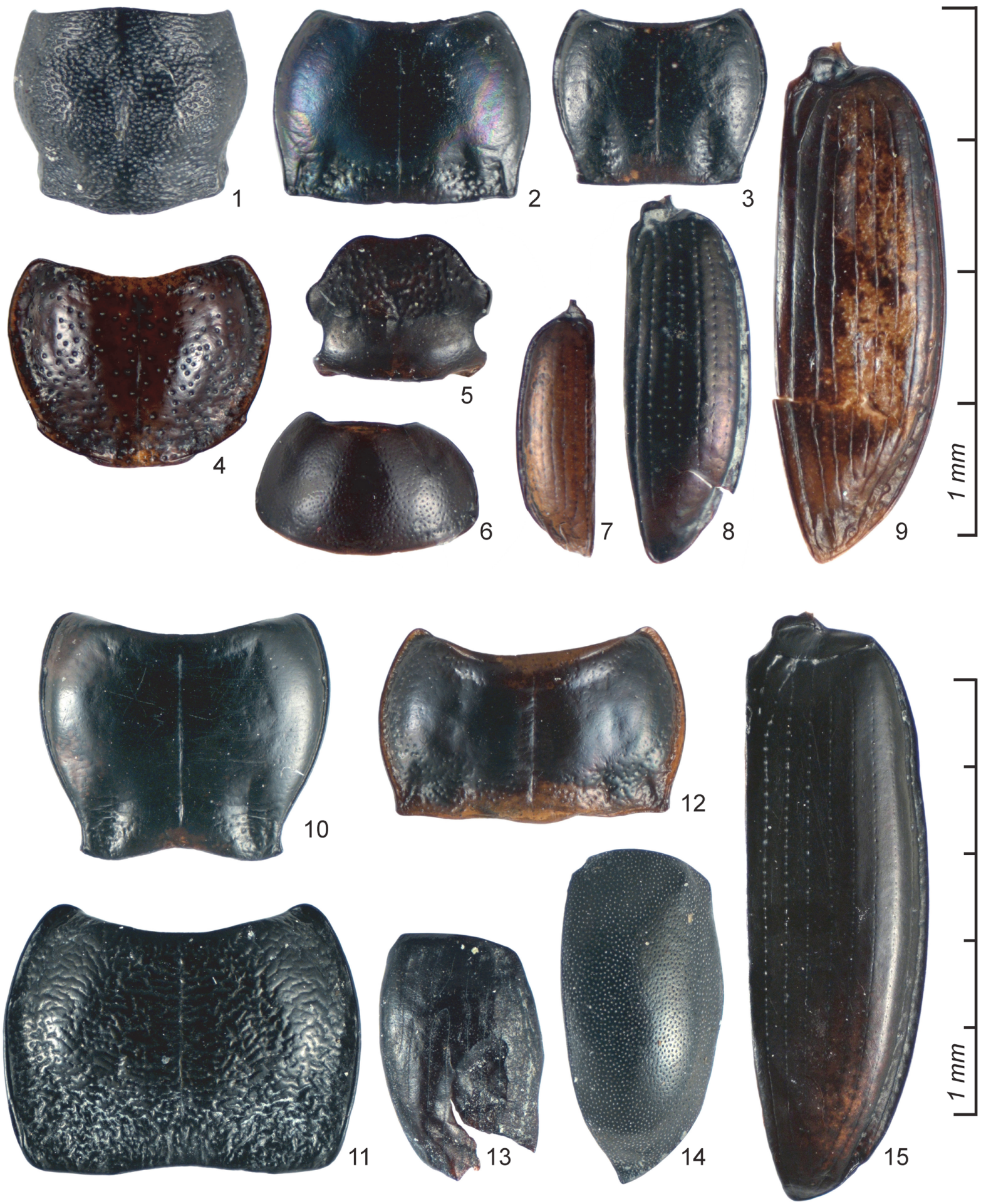

FIGURE 3. Subfossil beetle fragments from the Dubrovino assemblage; pronotum (1-4, 6, 10-12), head (5), and elytron (7-9, 13-15). 1, Elaphrus cf. riparius (Linnaeus, 1758); 2, Pogonus punctulatus Dejean, 1828; 3, Pterostichus cf. brevicornis (Kirby, 1837); 4, Cymindis cf. arctica Kryzhanovskij et Emetz, 1979; 5, Aphodius multiplex Reitter, 1867; 6, Cymbiodyta marginella (Fabricius, 1792); 7, Trechus cf. compactulus Belousov et Kabak, 1996; 8, Bembidion dauricum (Motschulsky, 1844); 9, Olisthopus sturmii (Duftschmid, 1812); 10, Pterostichus macer (Marsham, 1802); 11, P. mirus (Tschitschérine, 1894); 12, Amara aurichalcea Germar, 1823; 13, Porcinolus murinus (Fabricius, 1794); 14, Morychus ostasiaticus Tshernyshev, 1997; 15, Poecilus cf. ravus (Lutshnik, 1922). Scale bars are $1 \mathrm{~mm}$ increments. Figure parts 1-9 and 10-15 correspond to upper and the bottom scale bars, respectively. 

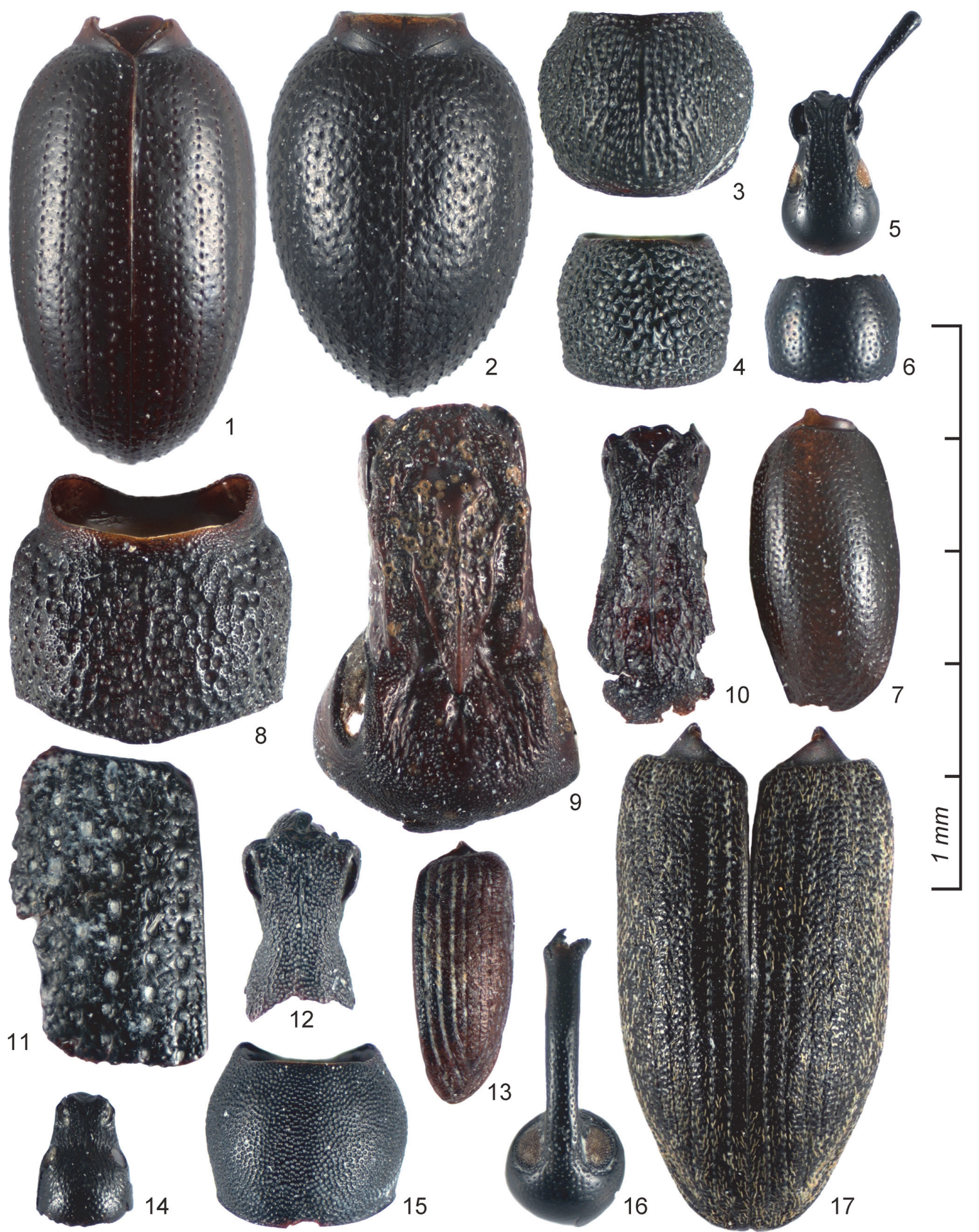

15

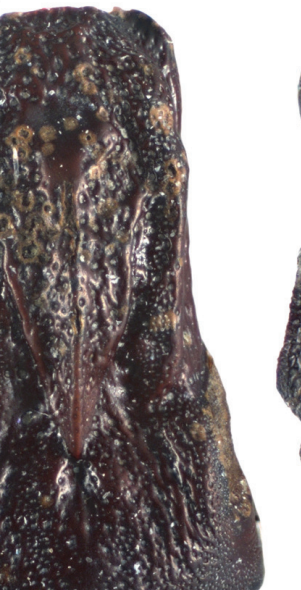




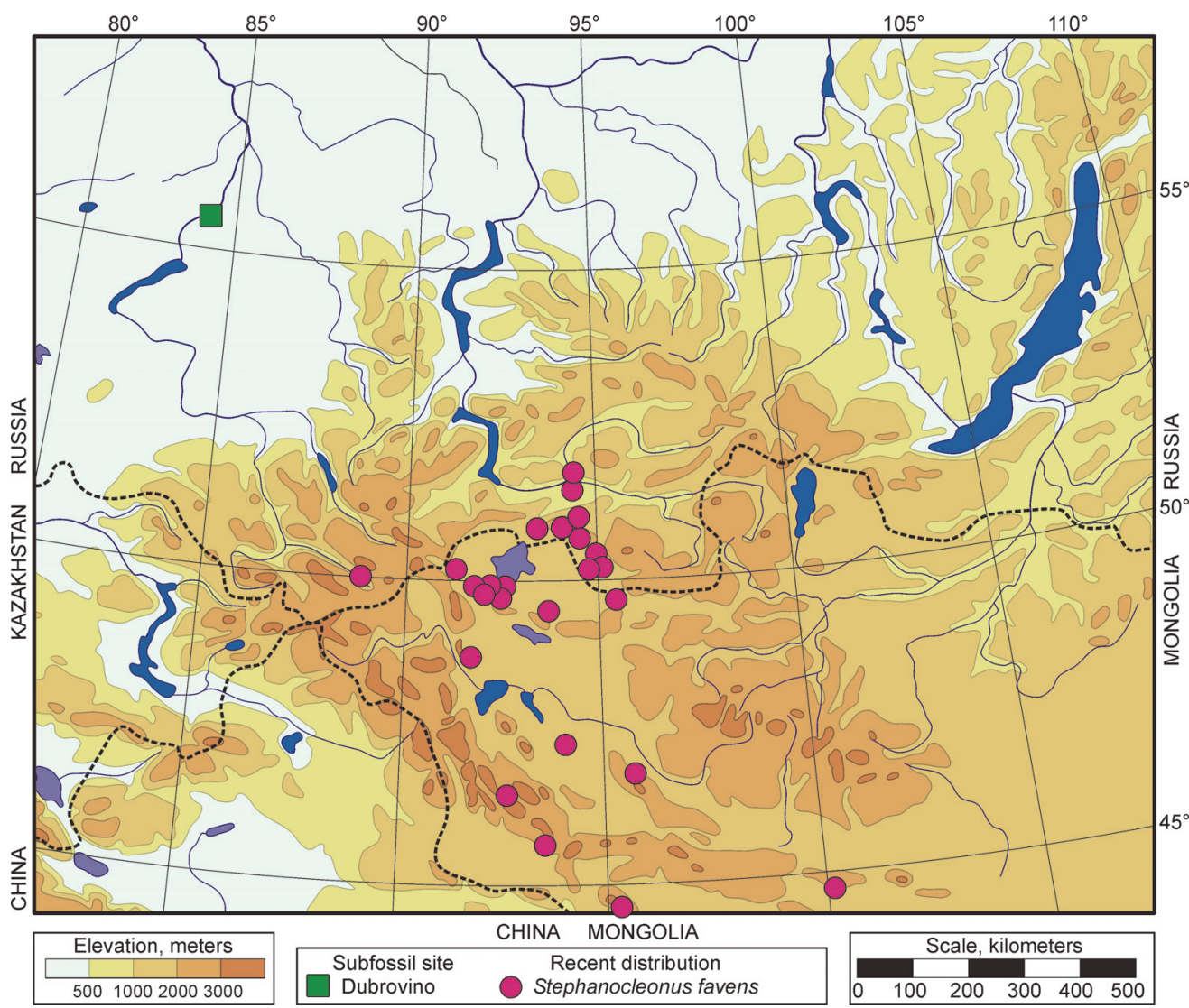

FIGURE 5. Late Pleistocene and modern ranges of Stephanocleonus favens Faust, 1884.

Quite diverse and abundant complex of species associated with moist habitats includes riparian species from the banks of streams (Nebria rubrofemorata; N. subdilatata Motschulsky, 1844), and species that occur near edge of shallow, standing water [Elaphrus riparius (Linnaeus, 1758); Cymbiodyta marginella (Fabricius, 1792); Cercyon sp.; Tournotaris bimaculatus (Fabricius, 1787); and Notaris aethiops]. Pterostichus mirus (Tschitschérine, 1894); Amara aurichalcea Germar, 1823; and Aegialia abdita Nikritin, 1975 inhabit river valleys, and Helophorus spp. represents the only aquatic beetle found.

The following species are associated with saline habitats: Pogonus iridipennis Nicolai, 1822; Pogonus punctulatus Dejean, 1828; and Centorus rufipes (Gebler, 1833).

Most of the phytophagous species from the assemblage feed plants of different families. Several species are associated with Carex L. (Tournotaris bimaculatus; Notaris aethiops), legumes (Tychius albolineatus; Hypera ornata; Sitona sp.), Brassicaceae (Ceutorhynchus ignitus), Umbelliferae (Lixus paraplecticus), chenopodiacious
(Metadonus distinguendus) and Salix L. (Lepyrus spp.; Chlorophanus sibiricus Gyllenhal in Schoenherr, 1834). Two species that feed exclusively on Larix Mill. (Hylobius excavatus and Pissodes insignatus) and several moss-feeding species (Byrrhidae) were found. A significant share of fragments belong to predatory Carabidae (28 species) and Coccinellidae (2 species).

\section{Comparison of the Fossil Species Composition with the Contemporary Fauna of the Region}

The recent fauna of the upper Ob River territory is distinctly different from those found in the Dubrovino deposit. Only a quarter of the species occur today in the upper Ob River north of Novosibirsk (Table 2). Actually, these species range in different zones and have a broad ecological tolerance. Most of the species identified from the study site are absent in the upper Ob River region today. These species range to North, South or East from the region (Table 2).

Eastern species represent the highest proportion $(28 \%)$ of the fossil assemblages. The recent range of eastern species includes the mountains of South Siberia. Some of them inhabit high elevation 


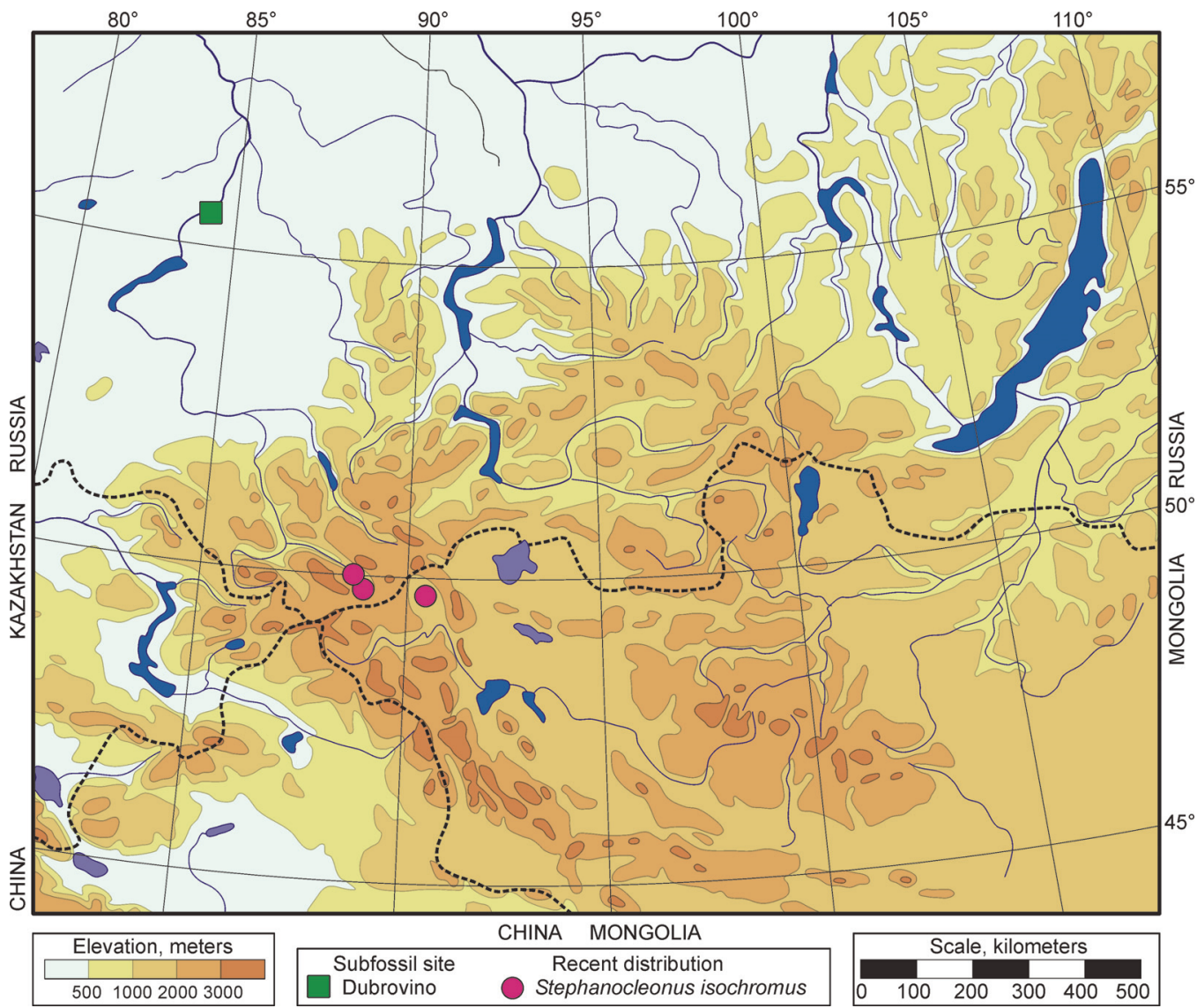

FIGURE 6. Late Pleistocene and modern ranges of Stephanocleonus isochromus Suvorov, 1912.

landscapes like mountain tundra or taiga (Nebria rubrofemorata; Pterostichus tomensis). Another species are the endemics of the mountain depressions and inhabit mostly steppe landscapes (Figures 5-7). Northern or boreal species were comparable with the recent ones. These are adapted to cold climatic conditions. Finally, southern species contribute one-fifth of the total species identified. These species are adapted to dry climatic conditions.

\section{Reconstruction of MIS 2 Conditions at the Fossil Site}

The species composition of insects in the Dubrovino deposit allows the reconstruction of a colder and more arid MIS 2 climate with strong steppic influences. The species with modern ranges to the north of the fossil site (Diacheila polita; Pterostichus (Cryobius) spp.; Notaris aethiops; Lepyrus nordenskioldi; and Hypera ornata) are indicators of colder-than-modern climate. The species of the steppe complex with modern ranges to south and sometimes to east from the Dubrovino site are indicators of dry climate. At the same time, the presence of forest-dwelling beetle species, including wood-feeding beetles, indicates the existence of forest vegetation in close proximity to the site. Thus, there may have been steppe landscapes at the site, developed under cold climatic conditions during the Last glaciation (MIS 2).

\section{DISCUSSION}

It is useful to compare the fossil insect fauna identified from the Dubrovino site with fossil assemblages from other sites in the central and southern parts of the West Siberian Plain (Figure 1) (Zinovyev, 2006, 2016; Zinovyev et al., 2016; Dudko et al., 2017; Gurina et al., 2018). The closest assemblage, in terms of chronology and locality, is from the Novaya Surtaika site on the right bank of the Isha River near its confluence with the Katun River in the foothills of the Northern Altai $\left(52^{\circ} 14^{\prime} \mathrm{N}, 85^{\circ} 55^{\prime} \mathrm{E} ; 21,389 \pm 400{ }^{14} \mathrm{C}\right.$ BP [SPb2299] and $18,248 \pm 250{ }^{14} \mathrm{C} \mathrm{BP}$ [SPb-2415], or $25,648 \pm 603 \mathrm{cal}$ yr BP and $21,918 \pm 390 \mathrm{cal} \mathrm{yr} \mathrm{BP)}$. The Novaya Surtaika fauna includes the coldadapted beetles, i.e., Diacheila polita; Pterostichus 


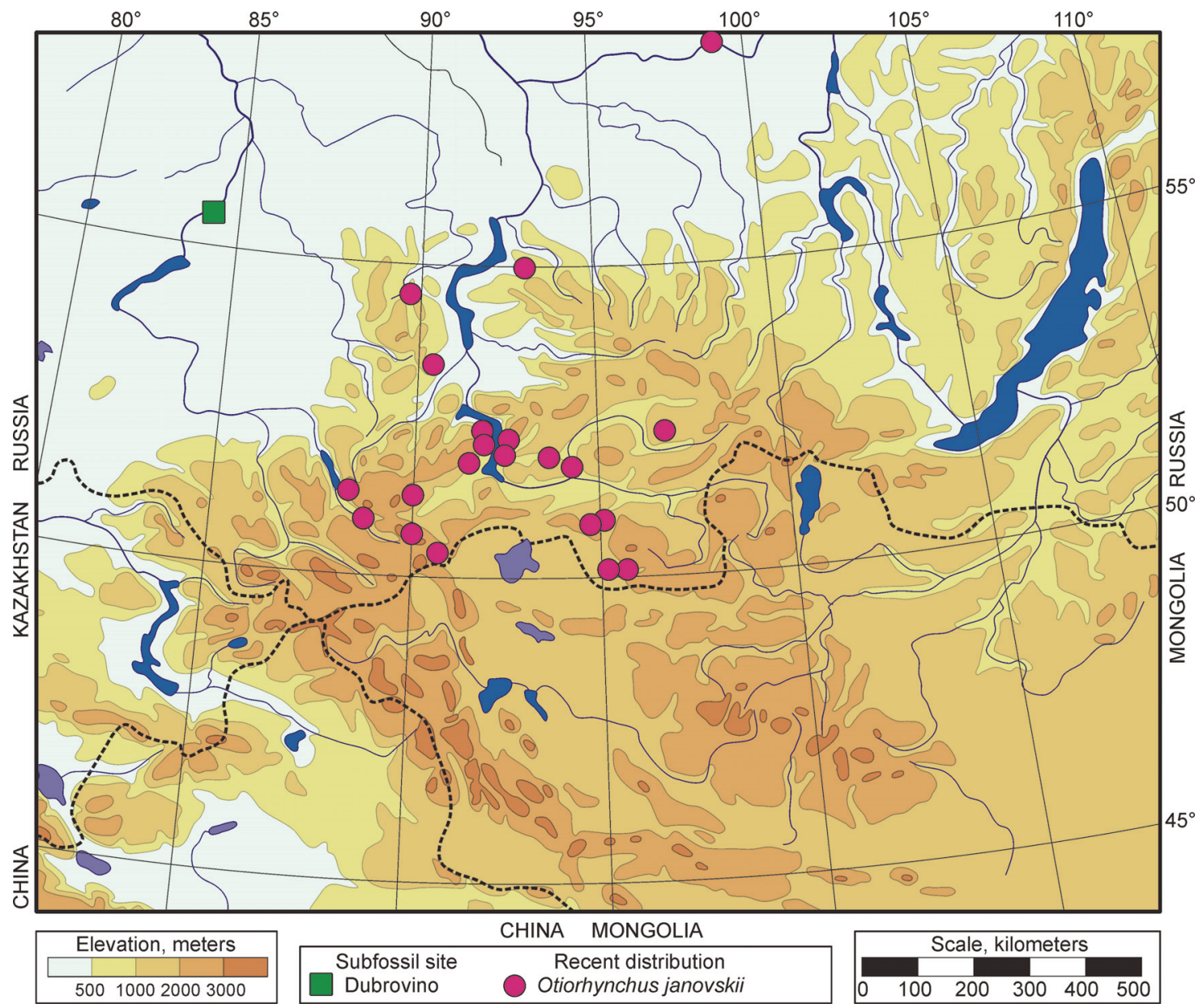

FIGURE 7. Late Pleistocene and modern ranges of Otiorhynchus janovskii Korotyaev, 1990.

(Cryobius) sp.; Hemitrichapion tschernovi (TerMinassian, 1973); and Cymindis vaporariorum (Linnaeus, 1758), characterizing a colder climate than today. In addition, this complex includes beetle species typical of modern subalpine meadows of the humid regions of Atai-Sayan mountains (Notiophilus jakovlevi Tschitschérine, 1903; Pterostichus drescheri (Fischer von Waldheim, 1817); Eutrichapion rhomboidale (Desbrochers des Loges, 1870); Notaris altaicus (Legalov, 1997); Otiorhynchus grandineus; and bark beetle species, i.e., Phloeotribus spinulosus (Rey in Eichhoff, 1883) and Polygraphus poligraphus (Linnaeus, 1758), developing on fir. The species composition of the assemblage allows us to conclude that environmental conditions in the foothills of the Northern Altai during MIS 2 coincide with the modern environments of the Central Altai region, at the elevation ca $1,700 \mathrm{~m}$ a.s.l. The presence of forest species indicates that this region served as a refugium for boreal, moisture-loving fauna (Dudko et al., 2017).
The sample from the center of the Kul'egan2247 profile $\left(60^{\circ} 25^{\prime} \mathrm{N}, 75^{\circ} 50^{\prime} \mathrm{E} ; 21,815 \pm 225^{14} \mathrm{C}\right.$ BP [SOAN-6837] or $26,091 \pm 553$ cal yr BP) relates to the MIS 2 period in the central part of the West Siberian Plain. Cold-adapted, boreo-arctic and arctic beetle species predominate, including Pterostichus costatus (Ménétriés, 1851); P. (Cryobius) spp.; Tachinus cf. arcticus (Motschulsky, 1860); and Curtonotus alpinus (Paykull, 1790). Specimens of Morychus cf. viridis Kuzmina and Korotyaev, 1987 were also found. Steppe species were completely absent. The species composition of the assemblage reflects cold climate conditions in an open landscape much like modern tundra (Zinovyev, 2006).

Similar fossil insect assemblages have been described from the Tyurseda-Khadyta site in South Yamal $\left(67^{\circ} 26^{\prime} \mathrm{N}, 69^{\circ} 57^{\prime} \mathrm{E}\right.$; $23,090 \pm 295$ and $20,970 \pm 690$ cal yr BP), and dominated by coldadapted species such as Tachinus cf. arcticus; Curtonotus alpinus; Pterostichus (Cryobius) spp.; Chrysolina cf. septentrionalis (Ménétriès, 1851); 
Lepyrus nordenskioldi; Notaris aethiops; and Isochnus arcticus (Korotyaev, 1977). The species composition of the Tyurseda-Khadyta assemblage reflects cold climate conditions and moss-dwarf shrub tundra landscapes (Zinovyev, 2016).

Thus, fossil beetle assemblages from the northern and central parts of the plain are all indicative of arctic environments associated with cold climate and tundra-like open landscapes. While in the south, there were likely areas of dry steppe formed under cold dry climate. In the region of the Altai foothills climate was cold but with moisture levels favourable for the development of woody vegetation. The Dubrovino fossil assemblage agrees with the reconstruction of cold climate in the central part of North Eurasia during MIS 2 (Volkova and Mikhailova, 2001).

The species composition of the Dubrovino assemblage is similar to that of the Kalistratikha $\left(52^{\circ} 58^{\prime} \mathrm{N}, 83^{\circ} 37^{\prime} \mathrm{E}\right.$; the end of MIS 3: $24,438 \pm 350$ ${ }^{14} \mathrm{C}$ BP [SPb-1416] or $29,222 \pm 567$ cal yr BP) and Bunkovo $\left(55^{\circ} 04^{\prime} \mathrm{N}, 82^{\circ} 30^{\prime} \mathrm{E}\right.$; the end of MIS 2: $11,550 \pm 125{ }^{14} \mathrm{C}$ BP [SOAN-8806] or $13,515 \pm 398$ cal yr BP) assemblages. Phytophagous beetles, especially the weevils Otiorhynchus altaicus $(=0$. karkaralensis Bajtenov, 1974) and O. ursus $(=0$. kasachstanicus Arnoldi, 1964), dominate these assemblages (Zinovyev et al., 2016; Gurina et al., 2018). The meadow complex is poorly represented, dominated by $O$. politus. Only a single species characterizes the forest complex. These facts indicate the presence of specific tundra-steppe landscapes with interspersed sparse coniferous trees and sparse meadow vegetation in the southern territories of the West Siberian Plain.

The results of Quaternary insect studies from deposits of the Last Glacial Maximum (beginning and middle period of MIS 2) from the territories of Western and Eastern Europe, and North-East Siberia, also indicate cold climatic conditions (Nazarov, 1979, 1984; Ponel, 1995; Kasse et al., 1998; Ponel et al., 2003; Sher et al., 2005).

The time interval ca 23,000-22,000 cal yr BP is considered the coldest period of the late Pleistocene in the Northern Hemisphere. This was the time of maximum glaciation north-west Eurasia and exposed shelves of the Arctic Ocean, extending from the British Islands in the west to the Novosibirsk Islands in the east (Hughes et al., 2016) that caused the formation of glacier-dammed lakes in the lowlands of West Siberia.

The climate was cold and dry due to large volumes of water frozen in continental ice sheets (Arkhipov and Volkova, 1994; Volkova et al., 2002; Simakova, 2006; Markova and Puzachenko, 2008; Simakova and Puzachenko, 2008; Hudges et al., 2016). The widest distribution of open tundra-type landscapes like periglacial forest-tundra, tundrasteppes or cold steppes with typical vertebrate faunas is characteristic of MIS 2 (ca 24,000-21,000 BP) (Simakova and Puzachenko, 2008).

\section{CONCLUSION}

A fossil insect assemblage from the Dubrovino site reflects cold and dry climate associated with the development of open landscapes with specific forest-steppe vegetation that differs from any modern environment. This reconstruction is supported by a number of cold- and dry-adapted species that are absent from this region today. Thus, the studied assemblage has no modern analogue, as the fossil assemblage species do not occur together in a single region today. Their modern ranges include localities that are north, south and east of the fossil locality. The characteristics of the fossil assemblage are compatible with the environmental conditions of the last (Sartan) glacial maximum in West Siberia, as reconstructed on the basis of entomological, vertebrate and palaeobotanical data (Arkhipov and Volkova, 1994; Borodin, 1996; Zinovyev, 2008). All these proxies clearly indicate the existence of cold-dry climate in the study region during MIS 2 .

\section{ACKNOWLEDGEMENTS}

The authors are gratitude to M.A. Kul'kova (Herzen State Pedagogical University, SaintPetersburg) for dating of the sample; we also thank M.S. Kireev (Novosibirsk) for the help in collecting of samples and V.K. Zinchenko (Novosibirsk) for the identification of some species. We are especially grateful to J. Cooter (Oxford University Museum of Natural History, UK) for his kind help with the final correction of the manuscript. The study was supported by the Russian Foundation for Basic Research (grant No. 16-04-01049-a) and the Federal Fundamental Scientific Research Programme for 2013-2020, grant No. VI.51.1.5 (AAAA-A16-116121410121-7). 


\section{REFERENCES}

Arkhipov, S.A. and Volkova, V.S. 1994. Geological History, Landscapes and Climate of West Siberia during the Pleistocene. IGG SO RAN, Novosibirsk. (In Russian)

Arnoldi, L.V. 1964. Novye vidy zhukov-dolgonosikov (Coleoptera, Curculionidae) iz Tsentralnogo Kazakhstana (New species of weevils (Coleoptera, Curculionidae) from Central Kazakhstan). Trudy Zoologicheskogo Instituta, 34:164-171. (In Russian)

Bajtenov, M.S. 1974. Zhuki roda Otiorhynchus Germar (Coleoptera, Curculionidae) v Kazakhstane (Weevils of the genus Otiorhynchus Germar (Coleoptera, Curculionidae) in Kazakhstan). Trudy Insituta Zoologii, 35:158-192. (In Russian)

Belousov, I.A. and Kabak, I.I. 1996. To the knowledge of the Asiatic species of the genus Trechus Clairville (Insecta: Coleoptera: Carabidae). Annalen des Naturhistorischen Museums in Wien, 98B:361-398.

Borodin, A.V. 1996. Quaternary small mammal faunas from the West Sibirian plain. Acta Zoologica Cracovensia, 39:75-81.

Buckland, P.C. and Coope, G.R. 1991. A Bibliography and Literature Review of Quaternary Entomology. University of Sheffield, Sheffield.

Capiomont, G. 1868. Révision de la tribu des hypérides, Lacordaire, et en particulier des genres Hypera Germ, Limobius, Schönh. et Coniatus (Germ.) Schönh. renfermant la description de plusieurs genres nouveaux et de 85 espèces nouvelles. Annales de la Société Entomologique de France, 4(8):161-286. (In French)

Chaudoir, M. 1850. Supplément à la faune des carabiques de la Russie. 4. Trois espèces nouvelles du groupe des Amaroides. Bulletin de la Société Impériale des Naturalistes de Moscou, 23:62-206. (In French)

Coope, G.R. 1959. A late Pleistocene insect fauna from Chelford, Cheshire. Proceedings of the Royal Society B: Biological Sciences, 151:70-86. https://dx.doi.org/10.1098/rspb.1959.0051

Coope, G.R. and Lemdahl, G. 1995. Regional differences in the Lateglacial climate of northern Europe based on coleopteran analysis. Journal of Quaternary Science, 10:391-395. https:// doi.org/10.1002/jqs.3390100409

Dejean, P.F.M.A. 1828. Species Général des Coléoptères, de la Collection de M. le Comte Dejean. Tome Troisième. Méquignon-Marvis, Paris. (In French)

Desbrochers des Loges, J. 1870. Description d'apionides et de quelques autres espèces de curculionides nouveaux. Mittheilungen der Schweizerischen Entomologischen Gesellschaft, 3:179-205. (In French)

Dudko, R.Yu., Gurina, A.A., Dudko, E.R., Zinovyev, E.V., Tshernyshev, S.E., and Legalov, A.A. 2017. Beetles (Coleoptera) in the late Pleistocene deposits on the Isha River in the foothills of the Northern Altai Mountains, p. 166-167. In Barkalov, A.V. (ed.), XV Congress of the Russian Entomological Society. Russia, Novosibirsk, July 31-August 7, 2017. Materials of the Congress. Garamond Publication, Novosibirsk.

Duftschmid, C.E. 1812. Fauna Austriae, oder Beschreibung der Österreichischen Insekten für Angehende Freunde der Entomologie. Zweyter Theil. Akademie Buchhandlung, Linz and Leipzig. (In German)

Eichhoff, W.J. 1883. Les Xylophages d'Europe. Avec des notes et additions concernant la faune gallo-rhénane. (Suite et fin.). Revue d'Entomologie, 2:121-145, plates 2-3. (In French)

Elias, S.A. 1994. Quaternary Insects and Their Environments. Smithsonian Institution Press, Washington.

Fabricius, J.C. 1775. Systema Entomologiae, Sistens Insectorum Classes, Ordines, Genera, Species Adiectis Synonymis, Locis, Descriptionibus, Observationibus. Officina Libraria Kortii, Flensburg and Leipzig. (In Latin)

Fabricius, J.C. 1787. Mantissa Insectorum Sistens eorum Species Nuper Detectas Adiectis Characteribus Genericis, Differentiis Specificis, Emendationibus, Observationibus. Tom. I. Impensis Christ. Gottl. Proft, Copenhagen. (In Latin)

Fabricius, J.C. 1792. Entomologia Systematica Emendata et Aucta. Secundum Classes, Ordines, Genera, Species Adjectis Synonimis, Locis, Observationibus, Descriptionibus. Tomus I. Pars I. Impensis Christ. Gottl. Proft, Copenhagen. (In Latin) 
Fabricius, J.C. 1794. Entomologia Systematica Emendata et Aucta. Secundum Classes, Ordines, Genera, Species Adjectis Synonimis, Locis, Observationibus, Descriptionibus. Tom IV. C.G. Proft, Fil. et Soc., Copenhagen. (In Latin)

Fabricius, O. 1780 Fauna Groenlandica, Systematice Sistens Animalia Groenlandiae Occidentalis Hactenus Indagata, Quoad Nomen Specificum, Triviale, Vernaculumque; Synonymia Auctorum Plurium, Descriptionem, Locum, Victum, Generationem, Mores, Usum, Capturamque Singuli, prout Detegendi Occasio Fuit, Maximaque Parte Secundum Proprias Observationes. Impensis Johannis Gottlob Rothe, Aulae atque Univers. Reg. Bibliopolae, Copenhagen and Leipzig. (In Latin)

Faldermann, F. 1835. Coleopterorum ab illustrissimo Bungio in China boreale, Mongolia et montibus Altaicus collectorum, nec non ab ill. Turczaninoffio et Stschukino e provincia Irkutzk missorum illustrationes. Mémoires présentés à l'Académie impériale des Sciences de StaintPétersbourg par Divers Savans et lus dans ses Assemblées, 2:337-464. (In Latin)

Faust, J. 1884. Russische Rüsselkäfer. Entomologische Zeitung (Stettin), 45:449-472. (In German)

Faust, J. 1890. Beiträge zur Kenntnis der Coleopteren-Fauna Südwest-Sibiriens. Verzeichniss der auf einer Reise in dem Minusinskischen Kreise und dem angrenzenden Theil der Mongolei von den Herren K. Ehnberg und R. Hammarström gesammelten Curculioniden. Öfversigt af Finska Vetenskaps-Societetens Förhandlingar, 32:53-106. (In German)

Fischer von Waldheim, G. 1817. De coleopteris quibusdam novis. Mémoires de la Société Impériale des Naturalistes de Moscou, 5:463-471. (In Latin)

Fischer von Waldheim, G. 1823. Entomographie de la Russie, et Genres des Insectes. Entomographia Imperii Rossici, sue Caesareae Majestati Alexandro I dicata, Tome II. Augusti Semen, Moscow (In French)

Forster, J.R. 1771. Novae Species Insectorum. Centuria I. Nom Mihi Contuenti se Persuasit Rerum Natura, Nihil Incredible Existimare de ea. Plin. Lib. XI.C.2. T. Davies and B. White, London. (In Latin)

Gebler, F.A. 1832. Notice sur les coléoptères qui se trouvent dans le district des mines de Nertschinsk, dans la Sibérie orientale, avec la description de quelques espèces nouvelles. Nouveaux Mémories de la Société Impériale des Naturalistes de Moscou, 2: 23-78. (In French)

Gebler, F.A. 1833. Notae et addidamenta ad catalogum Coleopterorum Sibiriae occidentalis et confinis Tatariae operis, C. F. von Ledebours Reise in das Altaigebirge und die soongarische Kirgisensteppe (Zwyter Theil. Berlin 1830). Bulletin de la Société Imperiále des Naturalistes de Moscou, 6:262-309. (In Latin)

Gebler, F.A. 1844. Charakteristik der von Hn. Dr. Schrenk in den Jahren 1842 und 1843 in den Steppen des Dsungarei gefundenen neuen Coleopteren-Arten. Bulletin de la Classe Physico-Mathématique de l'Académie Impériale des Sciences de St.-Pétersbourg, 3:97-106. (In German)

Gebler, F.A. 1847. Verzeichniss der im Kolywano-Woskresenskischem Hüttenbezirke Süd-WestSibiriens beobachteten Käfer mit Bemerkungen und Beschreibungen. Bulletin de la Société des Naturalistes de Moscou, 20:263-361. (In German)

Germar, E.F. 1822. Fauna Insectorum Europae, 7. Car. Aug. Kümmelii, Halae. (In Latin)

Germar, E.F. 1823. Insectorum Species Novae aut Minus Cognitae, Descriptionibus Illustratae. Volumen Primum. Coleoptera. Impensis J. C. Hendelii et filii, Halle. (In Latin)

Gurina, A.A., Dudko, R.Yu., Zinovyev, E.V., Borodin, A.V., Tshernyshev, S.E., and Legalov, A.A. 2018. Late Pleistocene taphocoenosis of insects and small mammals from the upper reaches of the Ob River. Paleontological Journal, 52:1596-1608.

Hughes, A. L.C., Gyllencreutz, R., Lohne, Ø.S., Mangerud, J., and Svendsen, J.I. 2016. The last Eurasian ice sheets - a chronological database and time-slice reconstruction, DATED-1. Boreas, 45:1-45. https://doi.org/10.1111/bor.12142

Kasse, C., Huijzer, A.S., Krzyszkowski, D., Bohncke, S.J.P., and Coope, G.R. 1998. Weichselian Late Pleniglacial and Late-glacial depositional environments, Coleoptera and periglacial climatic records from central Poland (Bełchatow). Journal of Quaternary Science, 13:455469. https://doi.org/10.1002/(sici)1099-1417(1998090)13:5\%3C455::aid-jqs398\%3E3.3.co;2$\mathrm{k}$

Kirby, W. 1837. The insects, pp. 1-329. In Richardson, J. (ed.), Fauna Boreali-Americana; or the Zoology of the Northern Parts of British America: Containing Descriptions of the Objects of 
Natural History Collected on the Late Northern Land Expeditions, under Command of Captain Sir John Franklin, R.N. Norwich: J. Fletcher. R. Bentley, London.

Kiselev, S.V., Kolesnikov, S.F., and Rybakova, N.O. 1987. On the climate of the growing season in the formation of deposits of the "ice" complex on the river Omolon. Bulletin of the Moscow Society of Naturalists, Department of Geology, 62:113-119. (In Russian)

Korotyaev, B.A. 1977. Novye vidy zhukov-dolgonosikov (Coleoptera, Curculionidae) s ostrova Vrangelya. Trudy Zoologicheskogo Instituta Akademii Nauk SSSR, 70: 61-64. (In Russian)

Korotyaev, B.A. 1990. Materialy po faune zhukov nadsemeystva Curculionoidea (Coleoptera) Mongolii i sopredelnykh stran. Nasekomie Mongolii, 11:216-234. (In Russian)

Kryzhanovskij, O.L. and Emetz, V.M. 1979. Novyy vid zhuzhelitsy roda Cymindis Latr. (Coleoptera, Carabidae) iz Yakutii. Zoologichesky Zhurnal, 58:447-448. (In Russian)

Kuzmina, S.A. 2017. Macroentomology analysis: methods, opportunities, and examples of reconstructions of paleoclimatic and paleoenvironmental conditions in the Quaternary of the Northeastern Siberia. Contemporary Problems of Ecology, 10:336-349. https://doi.org/ 10.1134/S1995425517040035

Kuzmina, S.A. and Korotyaev, B.A. 1987. A new species of the byrrhid beetles of the genus Morychus Er. (Coleoptera, Byrrhidae) from the North-East of the USSR. Entomologicheskoe Obozreniye, 66:342-344. (In Russian)

Laicharting, J.N.E. 1781. Verzeichniss und Beschreibung der Tyroler-Insecten. I. Theil. Käferartige Insecten. Band I. Johann Casper Fuessly, Zürich. (In German)

Legalov, A.A. 1997. Neue Taxone aus den Familien Apionidae und Curculionidae der Rüsselkäfer (Coleoptera) aus Sibirien. Entomologica Basiliensia, 20:467-476. (In German)

Legalov, A.A., Dudko, R.Yu., and Zinovyev, E.V. 2016. Sub-fossil weevils (Coleoptera, Curculionoidea) from the central part of West Siberia provide evidence of range expansion during the last glaciations. Quaternary International, 420:233-241. https://doi.org/10.1016/ j.quaint.2015.11.043

Linnaeus, C. 1758. Systema Naturae per Regna Tria Naturae, Secundum Classes, Ordines, Genera, Species, cum Caracteribus, Differentiis, Synonymis. Tomus I. Edition decima, reformata. Laurentii Salvii, Stockholm. (In Latin)

Luchitskaia, I.O., Belaia, N.I., and Arbuzov, S.A. 2014. The Climate of Novosibirsk and Its Changes, Federal Service for Hydrometeorology and Environmental Monitoring, Siberian Regional Scientific and Research Hydrometeorological Institute. Nauka Press, Novosibirsk. (In Russian)

Lutshnik, V.N. 1922. O Platysmatina (Coleoptera, Carabidae). Trudy Stavropolskogo Selskokhozaystvennogo Instituta, 1:67-79. (In Russian)

Mäklin, F.W. 1855. Bidrag till Kännedom om Såkallade Vikarierande Former Bland Coleoptera $i$ Norden. J. C. Frenckell \& Son, Helsinki. (In Swedish)

Mannerheim, C.G. 1823. Monographia Pelophilarum, p. 34-42. In Hummel, A.D. (ed.), Essais Entomologiques, 1. Chancellerie privée du Ministère de l'Intérieur, St. Pétersbourg. (In Latin)

Markova, A.K. and Puzachenko, A.Yu. 2008. Mammal assemblages during the Late Glacial Maximum (<=24->=17 kyr BP), p. 117-160. In Kolfschoten, T. and Markova, A.K. (eds.), Evolution of the European Ecosystems during Pleistocene-Holocene Transition (24-8 kyr $B P)$. KMK Scientific Press, Moscow. (In Russian)

Marsham, T. 1802. Entomologia Britannica, Sistens Insecta Britanniae Indigena, Secundum Methodum Linnaeanam Disposita. Tomus I. Coleoptera. White and Taylor, London. (In Latin)

Medvedev, L.N. 1968. Methods and perspectives of using coleopterological analysis for the study of Quaternary deposits and the history of the formation of faunas, p. 115-123. In Pjavchenko, N.I. (ed.), The History of Vegetation Development in the Central Regions of the European Part of the USSR in Anthropogenesis. Nauka Press, Moscow. (In Russian)

Ménétriés, E. 1851. Insecten, p. 43-76, pl. 3. In Middendorff, A.Th.v. (ed.), Reise in den Äussersten Norden und Osten Sibiriens. Zweiter Band. Theil 1. Eggers \& Comp, St. Petersburg. (In German)

Morgan, A.V. 1969. A Pleistocene fauna and flora from Great Billing, Northamptonshire, England. Opuscula Entomologica, 34:109-129.

Morgan, A.V. 1988. Late Pleistocene and Early Holocene Coleoptera in the lower Great Lakes region. Bulletin of the Buffalo Society of Natural Sciences, 33:195-206.

Motschulsky, V. 1844. Insectes de la Sibérie rapportés d'un voyage fait en 1839 et 1840. Mémoires Présentés a l'Académie Impériale des Sciences de St.-Pétersbourg par Divers Savans et lus dans ses Assemblées, 5:1-274. (In French) 
Motschulsky, V. 1860. Catalogue des insectes rapportes des environs du fl. Amour, depuis la Schilka jusqu'à Nikolaevsk. Bulletin de la Société Impériale des Naturalistes de Moscou, 32:487-507. (In French)

Müller, O.F. 1776. Zoologiae Danicae Prodromus, seu Animalium Daniae et Norvegiae Indigenarum Characteres, Nomina, et Synonyma Imprimis Popularium. Typis Hallageriis, Copenhagen. (In Latin)

Nazarov, V.I. 1979. Coleoptera from the Rubezhnitsa locality and their environment. Paleontological Journal, 13:462-470.

Nazarov, V.I. 1984. Reconstruction of landscapes of Byelorussia according to paleoentomological data (anthropogen). Proceedings of the Paleontological Institute of the Academy of Sciences of the USSR, 205:1-96. (In Russian)

Nicolai, E.A. 1822. Dissertatio inauguralis medica sistens Coleopterorum species agri Halensis quam consensu illustrissimi medicorum ordinis in celeberrima Academia Fridericiana Halensi et Vitebergensi consociata pro summis in medicina et chirurgia honoribus rite obtinendis. Die X. mensis septembris MDCCCXXII. Publice defendet auctor Ernestus Augustus Nicolai Arnstadio-Thuringus. F.A. Grunert, Halle. (In Latin)

Nikritin, L.M. 1975. Novyi vid roda Psammoporus (Col. Scarab.) iz Mongolii. Nasekomye Mongolii, 6:108-109. (In Russian)

Paykull, G. 1790. Monographia Caraborum Sueciae. J.F. Edman, Uppsala. (In Latin)

Paykull, G. 1792. Monographia Curculionum Sueciae. Litt. Viduae Direct. J. Edman, Uppsala. (In Latin)

Paykull, G. 1800. Fauna Svecica. Insecta. Tomus III. J.F. Edman, Uppsala. (In Latin)

Ponel, Ph. 1995. Rissian, Eemian and Würmian Coleoptera assemblages from La Grande Pile (Vosges, France). Palaeogeography, Palaeoclimatology, Palaeoecology, 114:1-41. https:// doi.org/10.1016/0031-0182(95)00083-x

Ponel, Ph., Orgeas, J., Samways, M.J., Andrieu-Ponel, V., De Beaulieu, J., Reille, L.M., Roche, P., and Tatoni, T. 2003. 110000 years of Quaternary beetle diversity change. Biodiversity and Conservation, 12:2077-2089. https://doi.org/10.1023/A:1024121327109

Reitter, E. 1867. Coleopterologische Notizen. LXII. Wiener Entomologische Zeitung, 16:241-242. (In German)

Sahlberg, J. 1887. Bidrag till Tschuktsch-halföns Insektfauna. Coleoptera och Hemiptera, insamlade under Vega-expeditionen vid halföns norra och östra kust, 1878-1879. VegaExpeditionens Vetenskapliga lakttagelser Bearbetade af Deltagare i Resan och Andra Forskare, 4:1-42. (In German)

Sahlberg, J.R. 1903. Coleoptera mediterranea et rosso-asiatica nova et minus cognita, maxima ex parte itirenibus annis $1895-1896$ et $1898-1899$ collecta. II. Öfversigt af Finska Vetenskaps-ocietetens Forshandlingar, 45:1-40. (In Latin)

Schaller, J.G. 1783. Neue Insecten. Abhandlungen der allischen Naturforschenden Gesselschaft, 1:217-328. (In German)

Schoenherr, C.J. 1834. Genera et Species Curculionidum, cum Synonymia Hujus Familiae. Species Novae aut Hactenus Minus Cognitae, Descriptionibus a Dom. Leonardo Gyllenhal, C. H. Boheman, et Entomologis Aliis Illustratae. Roret, Paris. (In Latin)

Schoenherr, C.J. 1839. Genera et Species Curculionidum, cum Synonymia Hujus Familiae. Species Novae aut Hactenus Minus Cognitae, Descriptionibus Dom. L. Gyllenhal, C. H. Boheman, O. J. Fahraeus et Entomologis Aliis Illustratae. Tomus quintus, pars prima. Supplementum continens. Roret, Paris. (In Latin)

Schoenherr, C.J. 1842. Genera et Species Curculionidum, cum Synonymia hujus Familiae. Species Novae aut Hactenus Minus Cognitae, Descriptionibus a Dom. Leonardo Gyllenhal, C. H. Boheman, O. J. Fåhraeus, et Entomologiis Aliis Illustratae. Tomus sextus. Pars secunda. Roret, Paris. (In Latin)

Schoenherr, C.J. 1843. Genera et Species Curculionidum, cum Synonymia hujus Familiae. Species Novae aut Hactenus Minus Cognitae, Descriptionibus a Dom. Leonardo Gyllenhal, C. H. Boheman, et Entomologis Aliis Illustratae. Tomus septimus. Pars secunda. Roret, Paris. (In Latin)

Sher, A.V., Kuzmina, S.A., Kuznetsova, T.V., and Sulerzhitsky, T.D. 2005. New insights into the Weichselian environment and climate of the East Siberian Arctic, derived from fossil insects, plants and mammals. Quaternary Science Reviews, 24:533-569. https://doi.org/10.1016/ j.quascirev.2004.09.007 
Shilenkov, V.G. 1975. Taksonomicheskiy obzor zhuzhelits roda Nebria Latr. (Coleoptera, Carabidae) Sibiri i Dalnego Vostoka SSSR. Entomologicheskoe Obozrenie, 54:830-845. (In Russian)

Simakova, A.N. 2006. The vegetation of the Russian Plain during the second part of the late Pleistocene (33-18 ka). Quaternary International, 149:110-114. https://doi.org/10.1016/ j.quaint.2005.11.024

Simakova, A.N. and Puzachenko, A.Yu. 2008. The vegetation during the Last Glacial Maximum (<=24->=17 kyr BP), p. 315-341. In Kolfschoten T. and Markova A.K. (eds), Evolution of the European Ecosystems during Pleistocene-Holocene Transition (24-8 kyr BP). KMK Scientific Press, Moscow. (In Russian)

Stierlin, W.G. 1861. Revision der europäischen Otiorhynchus-Arten. Berliner Entomologische Zeitschrift, 5:1-344. (In German)

Suvorov, G.L. 1912. Neue Genera und Arten der Curculionidae (Coleoptera) aus dem Palaearktischen Faunengebiete. Russkoe Entomologicheskoe Obozrenie, 12:468-490. (In German)

Ter-Minassian, M.E. 1973. Novyy vid roda Apion (Coleoptera, Apionidae) s Tayjmyra. Zoologichesky Zhurnal, 52(4):615-616. (In Russian)

Tschitschérine, T. 1894. Diagnoses de quelques nouvelles espèces de la tribu des Féroniens. Horae Societatis Entomologicae Rossicae, 28:254-258. (In French)

Tschitschérine, T. 1903. Notice sur divers Notiophilus Dum. Horae Societatis Entomologicae Rossicae, 36:108-117. (In French)

Tsepelev, K.A., Zinovyev, E.V., Dudko, R.Yu., Tshernyshev, S.E., and Legalov, A.A. 2013. Carrion beetles (Coleoptera, Silphidae) in Younger Dryas of Chick River (Late Pleistocene of Siberia). Evraziatskii Entomologicheskii Zhurnal, 12:27-34. (In Russian)

Tshernyshev, S.E. 1997. Towards the knowledge of the genus Morychus Er. (Coleoptera, Byrrhidae) in Russia. Entomologica basiliensia, 20:115-132.

Tshernyshev, S.E., Tsepelev, K.A., Dudko, R.Yu., Zinovyev, E.V., and Legalov, A.A. 2013. Pill beetles (Coleoptera, Byrrhidae) in late Pleistocene deposits in the south of the West Siberia. Evraziatskii Entomologicheskii Zhurnal, 12:109-119. (In Russian)

Volkova, V.S., Arkhipov, S.A., Babushkin, A.E., Kul'kova, I.A., Gus'kov, S.A., Kuzmina, O.B., Levchuk, L.K., Mikhailova, I.V., and Sukhorukova, S.S. 2002. Stratigraphy of Oil and Gas Basins of Siberia. Cenozoic of West Siberia. SO RAN Publication, "GEO" branch, Novosibirsk. (In Russian)

Volkova, V.S. and Mikhailova, I.V. 2001. Environment and Climate in the Last (Sartan) glaciacion in West Siberia (according to palynological evidence). Geologiya i Geofizika, 42:678-689. (In Russian)

Zinovyev, E.V. 2006. Problems of ecological interpretation of Quaternary insect faunas from the central part of Northern Eurasia. Quaternary Science Reviews, 25:1821-1840. https://doi.org/ 10.1016/j.quascirev.2006.01.017

Zinovyev, E.V. 2008. A history of ground-beetle faunas of West Siberia and the Urals during the late Pleistocene to Holocene, 241-254. In Penev, L.D., Erwin, T.L., and Assmann, T. (eds.), Back to the Roots and Back to the Future. Towards a New Synthesis Amongst Taxonomic, Ecological and Biogeographical Approaches in Carabidology. Proceedings of the XIII European Carabidologists Meeting. Blagoevgrad, August 20-24, 2007. Pensoft Publishers, Sofia and Moscow.

Zinovyev, E.V. 2011. Sub-fossil beetle assemblages associated with the "mammoth fauna" in the late Pleistocene localities of the Ural Mountains and West Siberia. ZooKeys, 100:149-169. https://doi.org/10.3897/zookeys.100.1524

Zinovyev, E.V. 2016. Review of late Pleistocene and Holocene localities from the North Western Siberia and the Urals. Vestnik NVGU, 2:23-36. (In Russian)

Zinovyev, E.V., Dudko, R.Yu., Gurina, A.A., Prokin, A.A., Mikhailov, Yu.E., Tsepelev, K.A., Tshernyshev, S.E., Kireev, M.S., Kostyunin, A.E., and Legalov, A.A. 2016. First records of sub-fossil insects from Quaternary deposits in the southeastern part of West Siberia, Russia. Quaternary International, 420:221-232. https://dx.doi.org/10.1016/j.quaint.2015.09.023 